\title{
Development of the Technology
}

\section{to Identify Firebreak Plowing Objects Based on the Satellite Data of the Earth Remote Sensing}

\author{
Eugene A. Maltsev* \\ Siberian Federal University \\ 79 Svobodny, Krasnoyarsk, 660041, Russia
}

Received 21.03.2017, received in revised form 15.06.2017, accepted 14.07.2017

This work describes the technology to identify firebreak plowing objects based on the satellite data of the Earth Remote Sensing within the medium and high special resolution.

Keywords: Earth Remote Sensing, firebreak plowing, classification.

\section{Разработка технологии распознавания объектов противопожарной вспашки \\ по спутниковым данным}

дистанционного зондирования Земли

Е.А. Мальцев

Сибирский федеральный университет Россия, 660041, Красноярск, пр. Свободный, 79

В работе представлена технология распознавания объектов противопожарной вспашки по спутниковым данным дистанционного зондирования Земли среднего и высокого пространственного разрешения.

Ключевые слова: дистанционное зондирование Земли, противопожарная вспашка, классификачия.

(C) Siberian Federal University. All rights reserved

* Corresponding author E-mail address: mtorrero@mail.ru 


\section{Introduction}

The paper [2] describes the information model of the firebreak plowing object. Firebreak plowing objects (FPO) on digital images of the Earth Remote Sensing (ERS) are objects of open soil with linear geometric structure and specific metrical, topological, spectral, and spatial parameters.

This paper shows the use of information model in the technology of FPO identification.

This technology is the set of methods and algorithms that allow recognizing the target objects based on satellite data of the Earth Remote Sensing at the medium and high spatial resolution, In addition, it allows identifying the territories requiring control over existing or missing FPO according to [6].

\section{Technology of FPO Identification}

The completed analysis of satellite images [2] shows that spectral specifications of target objects have values of spectral specifications of open soil, thus, applying general stages of interpretation of ERS images produces a sufficient number of type 1 classification errors (false positive). Therefore, the proposed technology contains the stage of territories location based on the model of the image relation structures $[1,7]$.

The technology includes the following stages:

- The selection of the input ERS data with account for cloudiness is performed based on the developed regional center of ERS [8] using antenna receiving complex;

- Preliminary processing of the input ERS data till 2A level and also georeference using reference points, atmospheric correction and estimation of cloudiness. The latter estimation is completed using the algorithm described in [3];

- Location of territories for further data processing;

- Segmentation of open soil objects;

- Classification of FBO;

- Estimation of classification accuracy.

\section{Location of Territories for Further Processing}

Territories location is completed for the purposes of future segmentation and classification using previously set classified objects as well as based on the set regulations for the search.

Thus, in order to identify the FBO the regulations of the territories search are based on [6].

Located areas of territories are areas of soil identified between the boundaries of agriculture fields (pursuant to crop rotation and excluding complete fallows) and adjacent previously classified objects: forest areas, automobile roads, railways, power lines.

Implementation of topological relations for the territories location applied in the information model [2]: O1 - 'disjoint', O2 - 'adjoint' is possible subject to using algorithms of computational geometry for intersecting polygons described in [5].

Realization of metrical relation $\mathrm{O}_{3}$ - 'distance between object boundaries less L' is possible subject to using the algorithm based on building the equidistant for a simple polygon and searching for its intersects with other polygons using Minkowski sum of a polygon with a disc with specified radius $[9,11,12]$ (Fig. 1). 
With the view to the weak dynamics in the change of classified data: forests, automobile roads, railways, and power lines it is possible to use previously classified objects. The objects are classified only once for the territories under research applying visual-expert method.

This paper proposes actualization of agriculture fields for the their existing map using ERS data of satellites SPOT and Landsat, as well as methods of controlled classification with learning sample subject to the calculation of normalized differential vegetation index (NDVI).

It should be noted that calculated located areas of territories can be used separately from technology as the information support of ground-based research and control of performing the fire protection regulations.

\section{Interpretation of Fire Protection Plowing Objects}

The first stage of interpretation is calculating NDVI for satellite image using the following expression (1):

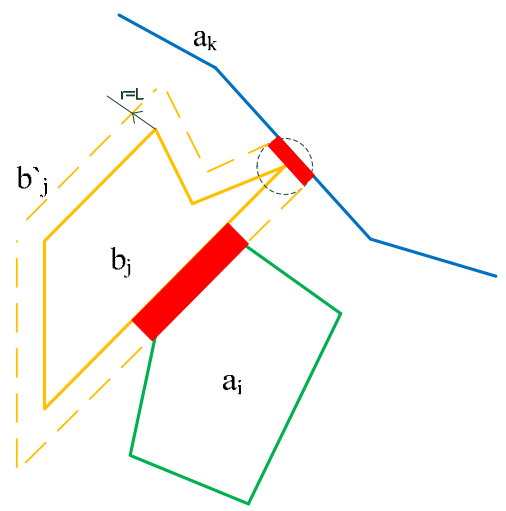

Fig. 1. Illustration of spatial objects relations (agriculture field - yellow color, forest - green color, automobile road - blue color)

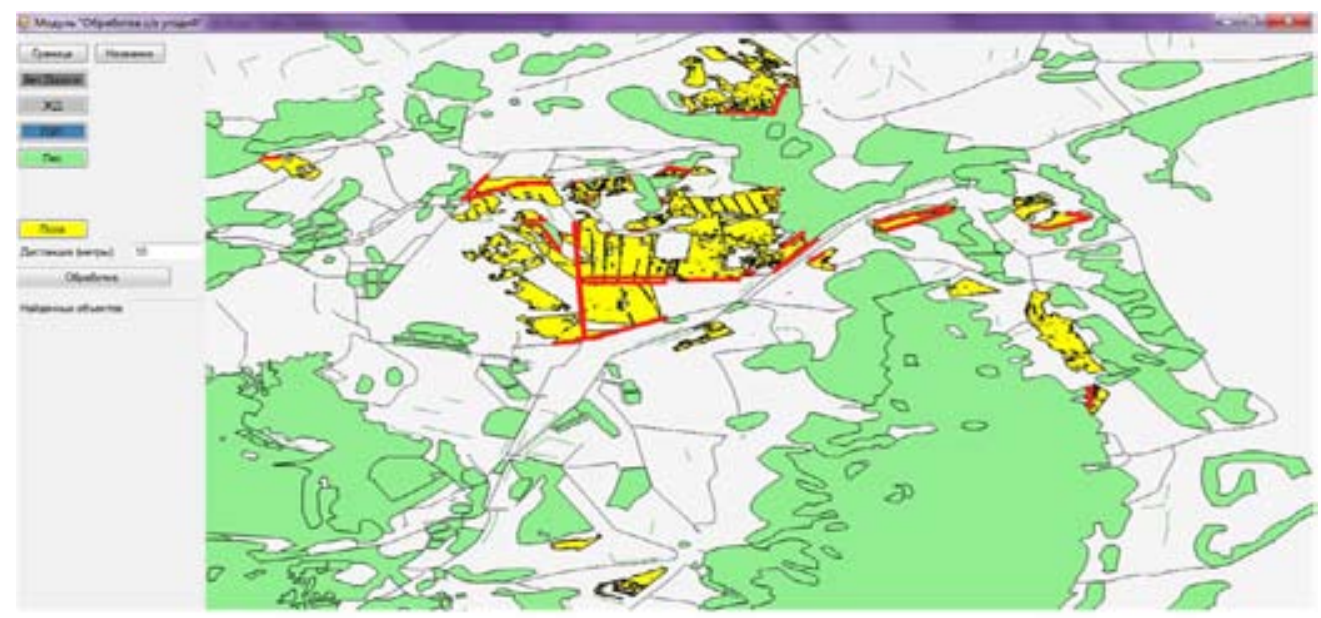

Fig. 2. Processed image with located territories for further interpretation (marked red) 


$$
\mathrm{NDVI}=\frac{\mathrm{NIR}-\mathrm{RED}}{\mathrm{NIR}+\mathrm{RED}},
$$

where: NDVI is a value of normalized differential vegetation index of satellite image pixel; NIR is a value of near infrared spectral channel (wavelength 0.76-1 micrometer); RED is a value of red spectral channel (wavelength 0.6-0.76 micrometer);

To solve the task of the open soil segmentation it is required to define the predicate LP ( $\omega)$ based on the spectral feature (NDVI value). NDVI values for the open soil are within the range $[10,4,7]$ :

$$
0.025 \leq \mathrm{NDVI} \leq 0.1
$$

Expression for LP $(\omega)$ :

$$
\operatorname{LP}(\omega)=\left\{\begin{array}{c}
\text { TRUE, if } 0.025 \leq \mathrm{NDVI}(\mathrm{f}(\mathrm{x}, \mathrm{y})) \leq 0.1 \\
\text { FALSE, otherwise }
\end{array}\right.
$$

where: $f(x, y)$ - function of brightness of satellite image pixel; NDVI - value of normalized differential vegetation index of satellite image point.

The rule for FPO classification is as follows: the selection of segments belongs to the set of located territories using predicate LP, moreover, the thickness of segments is greater than the specified threshold and the length is even more greater than thickness:

$$
\bar{g}(\omega)=\mathrm{T}(\omega)>c_{1} \text { AND } \omega \in \mathrm{W}_{1} \text { AND } \quad \mathrm{T}(\omega) \ll \mathrm{L}(\omega) \operatorname{AND} \mathrm{LP}(\omega),
$$

where $\mathrm{T}(\omega)$ - function of object thickness; $\mathrm{L}(\omega)$ - function of object length; $\mathrm{c}_{1}-$ set threshold of object thickness (4 meters for FPO); $\mathrm{W}_{1}-$ multitude of located territories areas. Euclidean distance is the metrics of the classifier.

\section{Experimental Research over Technology of FPO Identification}

Pursuant to main stages of the technology the expert selected the input satellite ERS data with the value of cloudiness being $5 \%$ using the catalogue of the regional ERS center data (Fig. 3). The catalogue is available on the Internet: http://digitalatlas.ru/. The next step of the technology is preliminary data processing.

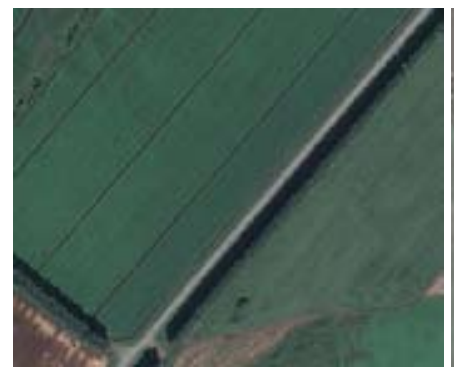

a)

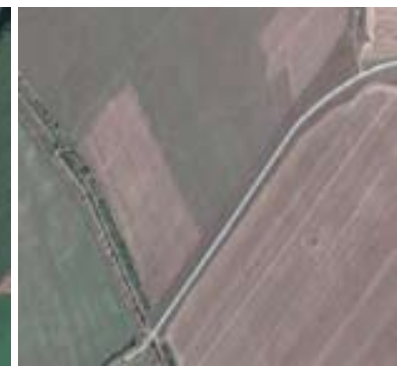

b)

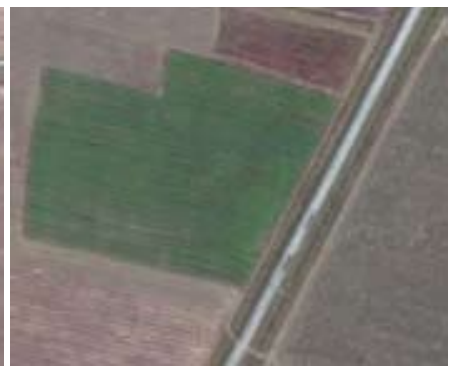

c)

Fig. 3. Fragments of ERS data obtained for different areas within Krasnoyarsk Territory: a) Fragment of satellite image SPOT 6 (6 m), August 2013; b) Fragment of satellite image SPOT 6 (6 m), September 2014; c) Fragment of satellite image SPOT 6 (6 m), August 2014 
Interpretation of additional objects (forests, automobile roads, railways, power lines) has been performed by the expert with ground-based researches and GPS binding.

The resulted vector layers are marked on Fig. 4. The scale of vector data is 1:10 000. Metrical georeferencing error is 4 meters.

The interpretation of additional objects was followed by location of territories areas to search FPO objects. For the latter purpose vector layers have been loaded to developed program module to locate FPO objects, territories have been selected for followed interpretation after processing (Fig. 5).

The next step of the technology is segmentation of open soil using the calculated NDVI for satellite images and classification of FPO objects (Fig. 6).

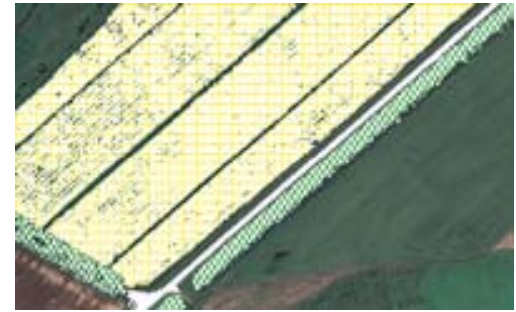

a)

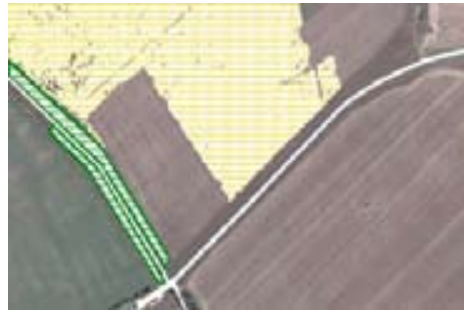

b)

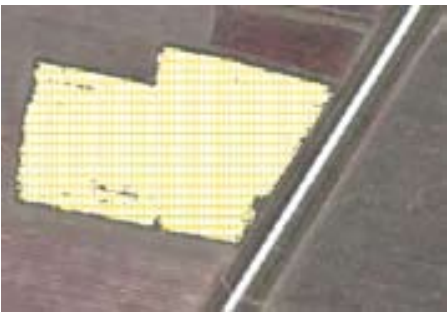

c)

Fig. 4. Fragments of ERS data with classified objects (automobile roads - white color; agriculture fields - yellow color; forest - green color)

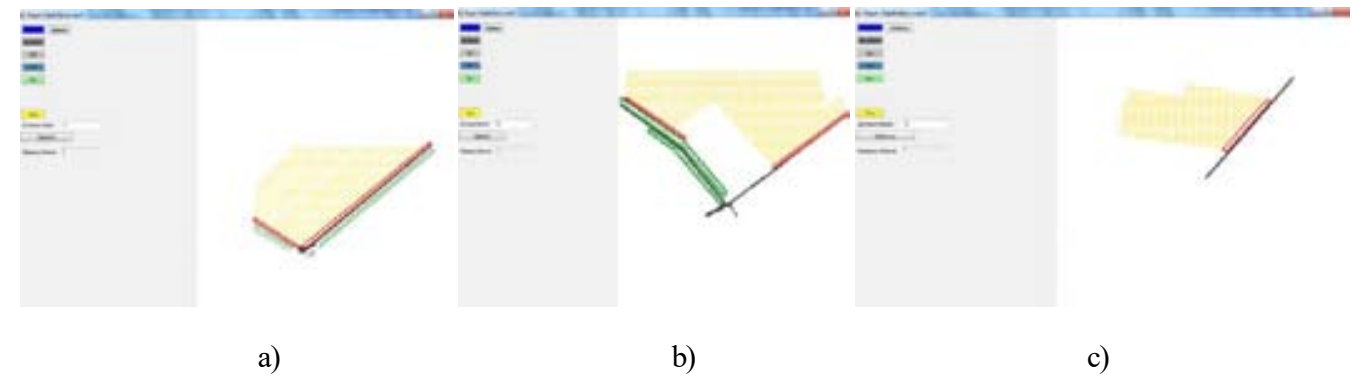

Fig. 5. Operation of the module for location of the FPO with selected territory areas for further data interpretation

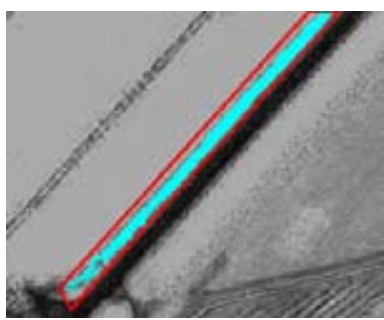

a)

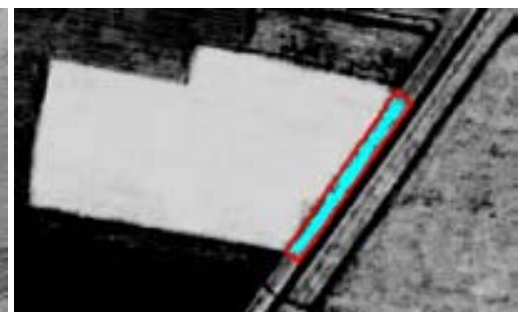

b)

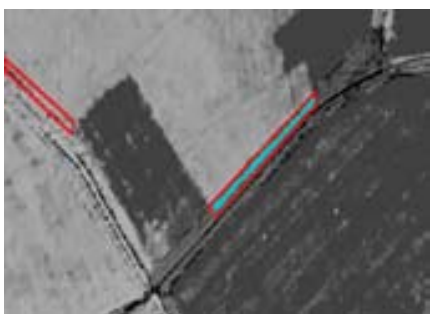

c)

Fig. 6. Images of the NDVI calculated on the basis of the satellite images with located territory areas for further interpretation (red color) and classified FPO object (blue color) 


\section{Conclusion}

The technology of FPO identification has been developed using information model described in [2].

Over 100 satellite images with high spatial resolution picturing the agricultural areas within Krasnoyarsk Territory have been processed using the proposed technology. The resulted classification accuracy is $93 \%$.

In addition, task solving allowed developing ancillary algorithms, methods, and software to identify FBO. Experimental research has been completed over the proposed technology within the agricultural areas of Krasnoyarsk Territory.

\section{References}

[1] Денисов, Д.А. Компьютерные методы анализа видеоинформации, Красноярск КГТУ, 1993, 192 c. [Denisov, D.A. Computer methods of video information analysis, Krasnoyarsk: KSTU, 1993. 192 p. (in Russian)]

[2] Мальцев Е.А., Маглинец Ю.А. Разработка информационной модели объекта «противопожарная вспашка» для автоматизированной обработки спутниковых данных. Региональные проблемы дистанционного зондирования Земли: материаль международной научной конференции г. Красноярск, Сибирский федеральный университет, 2014, 326-329. [Maltsev Ye.A., Maglinets Yu.A. Development of information model of the FPO for the automated processing of satellite data. Regional problems of the Earth Remote Sensing: materials of the international scientific conference in Krasnoyarsk, Siberian Federal University, 2014. 326-329. (in Russian)]

[3] Maltsev Ye.A., Sirotin E.Ye, Perfilyev D.A., Tsibulsky G.M. Extracting a Cluster of Clouds in the SPOT 4 Satellite Images, International Journal of "Pattern Recognition and Image Analysis. Advances in Mathematical Theory and Applications", vol. 21, 2011, No. 2, 501-504.

[4] Михайлов С. Советы из космоса. Агропрофи, Т.1, февраль 2009, 21-23. [Mikhaylov S. Advice from the space. Agroprofi, Vol. 1, February 2009, pp. 21-23. (in Russian)]

[5] Препарата Ф., Шеймос М. Вычислительная геометрия: Введение: Пер. с англ. М: Мир, 1989, 478 c. [Preparata F., Sheymos M., Computational Geometry: Introduction: Translated from English. M.: Mir, 1989, 478. (in Russian)]

[6] Приказ Министерства Российской Федерации по делам гражданской обороны, чрезвычайным ситуациям и ликвидации последствий стихийных бедствий от 18 июня 2003 г. № 313 ОБ УТВЕРЖДЕНИИ ПРАВИЛ ПОЖАРНОЙ БЕЗОПАСНОСТИ В РОССИЙСКОЙ ФЕДЕРАЦИИ (ППБ 01-03). [Order No. 313 issued by the Ministry of the Russian Federation for Civil Defense, Emergencies and Elimination of Consequences of Natural Disasters on June 18, 2003 "ON APPROVAL OF RULES FIRE SAFETY IN THE RUSSIAN FEDERATION” (Fire Safety Regulations 01-03) (in Russian)]

[7] Чандра А.М., Гош С.К. Дистаниионное зондирование и географические информационные системы. М: Техносфера, 2008. 312 с. [Chandra A.M., Gosh S.K. Remote sensing and geographic information systems. M.: Tekhnosfera, 2008. 312 p. (in Russian)]

[8] Цибульский, Ю.А. Маглинец, А.А. Латынцев и др. Многоцелевая региональная система дистанционного зондирования Земли Сибирского федерального университета. 
Проблемы информатизации региона. Материаль ХІ Всероссийской научно-практической конференции. Красноярск. 2009 г. 22-25 [Tsibulsky G.M., Maglinets Yu.A., Latyntsev A.A. et al. Multipurpose regional system of the Earth Remote Sensing of the Siberian Federal University. Problems of the regional information. Materials of the 11th All-Russian scientific-practical conference. Krasnoyarsk. 2009. 22-25. (in Russian)]

[9] Алгоритмы вычислительной геометрии. [Электронный ресурс] Режим доступа: http:// www.cgal.org/ [Algorithms of computational geometry. [Electronic resource] Access: http://www.cgal. org/ (in Russian)]

[10] Географические информационные системы и дистаниионоее зондирование. [Электронный ресурс] Режим доступа: http://gis-lab.info/qa/ndvi.html [Geographical information systems and remote sensing. [Electronic resource] Access: http://gis-lab.info/qa/ndvi.html (in Russian)]

[11] Ron Wein A CGAL Package for the Exact and Effcient Construction of Planar Minkowski Sums and Offsets using the Convolution Method. ACS Technical Report No.: ACS-TR-243400-02.

[12] Ron Wein Exact and approximate construction of offset polygons. Computer-Aided Design vol. 39, edition $6,2007,518-527$. 